\title{
Effects of alcohol on liver apparent diffusion coefficient values: A single center study
}

\author{
Alkolün karaciğer görünür difüzyon katsayısı değerleri üzerine etkileri: Tek merkez çalışması
}

\author{
(Dizzet ÖKÇESIZ1 , D Hakan ARTAŞ², (D Mehmet YALNIZ³ \\ Departmant of ${ }^{1}$ Radiology, Erciyes University School of Medicine, Kayseri \\ Departmants of ${ }^{2}$ Radiology, and ${ }^{3}$ Gastroenterology, Firat University School of Medicine, Elazığ
}

\begin{abstract}
Background and Aims: This study aimed to investigate the relationship between liver apparent diffusion coefficient values and potential early-stage liver injury by comparing apparent diffusion coefficient values obtained by liver diffusion-weighted magnetic resonance imaging between individuals with a history of excessive alcohol consumption and healthy volunteers. Materials and Methods: This study enrolled 35 individuals with a history of excessive alcohol consumption and 32 healthy volunteers. In all cases, blood samples were taken to measure biochemical parameters and complete blood count. Upper abdominal magnetic resonance imaging including liver diffusion-weighted imaging was performed. Results: In total, 19 individuals with a history of excessive alcohol consumption and 20 healthy volunteers were included in the study. The mean apparent diffusion coefficient values obtained by high $b$ value (b 1000) diffusion-weighted imaging in individuals with a history of excessive alcohol consumption were lower than those in healthy volunteers. Although no significant difference was observed between the two groups in terms of biochemical parameters, hepatic apparent diffusion coefficient values in both groups were positively correlated with international normalized ratio values and negatively correlated with gamma-glutamyl transferase and alkaline phosphatase levels ( $r=0.002, r=-0.007, r=-0.049$, respectively). Conclusion: Diffusion-weighted imaging is a noninvasive imaging technique that can be used for the detection and follow-up of liver fibrosis induced by alcohol consumption.
\end{abstract}

Key words: Alcohol, liver, diffusion-weighted magnetic resonance imaging

\section{INTRODUCTION}

Alcohol consumption is one of the major causes of liver cirrhosis. It stands out as the cause of approximately sixty diseases and pathological conditions, including cancer, and it is the third leading cause of premature death in Europe. Every year, approximately 2.5 million people die from alcohol-related medical problems.

Alcohol-related liver diseases range from fatty liver or liver steatosis to alcoholic hepatitis to chronic hepatitis to cirrhosis with hepatic fibrosis (1). The American Gastro-

Correspondence: Izzet ÖKÇESiz

Erciyes University School of Medicine, Departmant of Radiology, 38039

Kayseri/Turkey• Tel: +90 3522076666

E-mail: drizzetokcesiz@yahoo.com
Giriş ve Amaç: Bu çalışmada aşırı alkol tüketimi öyküsü olan bireyler ve sağlıklı gönüllüler arasında karaciğer diffüzyon ağırlıklı manyetik rezonans görüntüleme ile elde edilen görünür diffüzyon katsayısı değerlerini karşılaştırarak, karaciğer görünür diffüzyon katsayısı değerleri ile potansiyel erken evre karaciğer hasarı arasındaki ilişkiyi araştırmak amaçlanmıştır. Gereç ve Yöntem: Aşırı alkol tüketimi öyküsü olan 35 kişi ve 32 sağlıkı gönüllü bu çalışma için planlanmıştır. Tüm olgularda biyokimyasal parametreleri ölçmek ve tam kan sayımı için kan örnekleri alınmış olup, karaciğer diffüzyon ağırlıklı görüntülemeyi içeren üst abdominal manyetik rezonans görüntüleme yapılmıştır. Bulgular: Aşırı alkol tüketimi öyküsü olan 19 birey ve 20 sağlıklı gönüllü çalışmaya dahil edilmiştir. Aşırı alkol tüketimi öyküsü olan bireylerde yüksek $b$ değeri (b 1000) diffüzyon ağırlıklı görüntülemeyle elde edilen ortalama görünür diffüzyon katsayısı değerleri, sağlıklı gönüllülerden daha düşük bulunmuştur. Her iki grup arasında biyokimyasal parametreler açııından anlamlı bir fark gözlenmese de, her iki gruptaki karaciğer görünür diffüzyon katsayısı değerleri uluslararası normalizasyon oranı değerleri ile pozitif, gama-glutamil transferaz ve alkalen fosfataz değerleri ile negatif korelasyon göstermiştir (sırasıyla $r=0.002, r=-0.007, r=-0.049$ ). Sonuç: Diffüzyon ağırlıklı görüntüleme, alkol tüketiminin neden olduğu karaciğer fibrozisinin saptanması ve takibi için kullanılabilecek noninvaziv bir görüntüleme tekniğidir.

Anahtar kelimeler: Alkol, karaciğer, diffüzyon ağırlıkı manyetik rezonans görüntüleme

enterological Association, the American Association for the Study of Liver Diseases and the American College of Gastroenterology have a consensus definition of excessive alcohol consumption which stipulates that it must occur over a two year period and be at a rate of $210 \mathrm{~g}$ per week for men and $140 \mathrm{~g}$ per week for women.

Diffusion-weighted magnetic resonance imaging (DWI) measures the random motion of water molecules in tissues. It is a single breath holding imaging technique that

Ökçesiz I, Artaş H, Yalnız M. Effects of alcohol on liver apparent diffusion coefficient values: A single center study. The Turkish Journal of Academic Gastroenterology 2021;20:19-26. DOI: 10.17941/agd.927185

Manuscript Received: 27.11.2019 • Accepted: 10.04.2020 
doesn't require a contrast agent for the imaging process. DWI was first introduced in neuroradiology for the early diagnosis of stroke. It is very sensitive to cardiorespiratory pulsatility and peristaltism, so it could only be used for brain imaging in the past. When fast magnetic resonance imaging (MRI) sequences such as echo-planar imaging developed, DWI could be used on other parts of the body. DWI is a part of routine MRI protocols for the diagnosis of focal or diffuse liver disease in many medical institutions today (2-4).

Previous studies showed that the mean liver apparent diffusion coefficient (ADC) values of patients with chronic liver disease and hepatic fibrosis were significantly lower than those of healthy individuals (5-7).

The aim of this study was to investigate the role of liver $A D C$ values in potential early stage liver injury related to alcohol consumption in heavy drinkers.

\section{MATERIALS and METHODS}

This study was approved by the Institutional Ethics Review board.

\section{Participants}

Thirty-five volunteers with excessive alcohol consumption and 32 healthy individuals with no known diseases were considered for the study. Blood samples for biochemical tests and complete blood count were obtained from all subjects, and upper abdominal magnetic resonance examinations were performed.

\section{Diffusion-Weighted Magnetic Resonance Imaging}

Upper abdominal MRI examinations were performed using a 1.5 Tesla scanner (Ingenia, Philips, NV, USA) with 32 channel body coil. All MRI examinations were performed after eight hours of fasting at approximately the same time of the day (between 08:00 and 12:00 a.m.). All individuals were prepared for the examination in the supine position with respiratory monitoring. They were all informed about the facts that would be observed during the examination. No sedation was administered prior to the examination.

In all cases, the following diffusion-weighted (DW) images were obtained: b0, b 400 and b 1000 values [Field of View (FOV): $40 \times 35 \mathrm{~cm}$; Matrix: 132×114; Number of Excitations (NEX): 2.0; slice thickness: $5 \mathrm{~mm}$, inter slice gap: $0.5 \mathrm{~mm}$; Repetition Time (TR) and Echo Time (TE): minimum, diffusion direct: all directions]; $A D C$ maps and T2-weighted fast spin echo images (FOV: 40×35 cm; Ma- trix: $288 \times 251$; NEX: 1.0 ; slice thickness: $5 \mathrm{~mm}$, inter slice gap: 0.5 mm; TE: 80 msn; TR: $441 \mathrm{msn}$ ).

\section{Image Analysis}

One radiologist interpreted all the DW images and ADC maps for liver $A D C$ measuring. The radiologist was blinded to the study groups for clinical details, laboratory findings and final diagnosis. All ADC measurements were performed using General Electric Company (GE) Advantage Workstation Release 4.6 Software. To measure liver $A D C$ values, operator-defined circular regions of interest (ROls) were used. Right lobe posterior liver parenchyma was selected on the ADC map to place on three ROIs, and liver ADC values were determined by averaging these measured $A D C$ values. ROls were carefully placed to avoid focal liver lesions and vessels. The ROIs sizes were $1 \mathrm{~cm}^{2}$ each (Figure 1).

\section{Blood Sample Analysis}

Blood samples were taken from all individuals after fasting for eight hours. Complete blood counts were measured using ABX Pentra DX 120 (Horiba), hepatic markers were analysed using ARCHITECT i1000SR (Abbott Diagnostics) and biochemical parameters were analysed using ADVIA 1800 Chemistry (Siemens Healthcare Diagnostics) devices. Statistical analysis was performed on these values.

\section{Statistical Analysis}

The data were statistically analysed using the Statistical Package for the Social Sciences (SPSS) version 20.0 for Windows. All values were expressed as mean \pm standard deviation, and values of $p<0.05$ were considered statistically significant. The differences between the parameters for the two groups were tested using the one-way analysis of variance (ANOVA) and Kruskal-Wallis variance analysis. The Pearson test was performed to evaluate the correlation between the two groups.

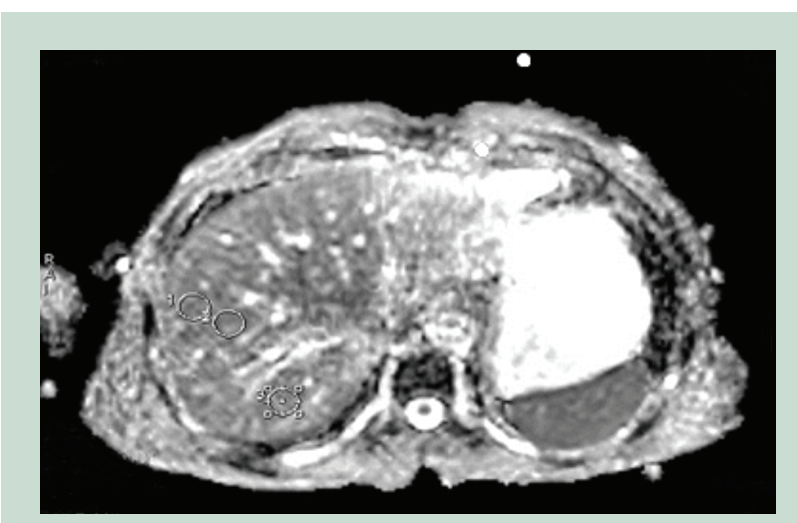

Figure 1. An example of ROI measurements. 


\section{RESULTS}

Nineteen of the 35 individuals with histories of excessive alcohol consumption, and 20 of the 32 healthy volunteers were included in the study. In the alcohol consumption group, six cases consumed less alcohol than the eligibility criteria for heavy alcohol consumption, so they were excluded from the study. Three cases were found to have hepatitis B infection and two cases had claustrophobia, so they were also excluded from the study. In the control group, there were three cases of hepatitis B infection, so they were excluded from the study. Two cases in the control group were excluded from the study because of claustrophobia. Five cases in the alcohol consumption group and seven cases in the control group were found to have liver steatosis by using signal loss compared to the in-phase in out-of phase upper magnetic resonance imaging, so they were excluded from the study.

Analysis of the images revealed the following: liver cysts in four cases, renal cysts in seven cases, liver haemangiomas in two cases, gallbladder polyps in one case and gall bladder bile duct stones in one case.

The alcohol consumption group consisted of 17 males and two females. In the control group, there were 15 males and 5 females. The mean age of the individuals in the alcohol consumption group was 39.3 \pm 13.7 (23$64)$ years, and the average age of the healthy volunteer group was $36.1 \pm 10.1$ (22-54) years. There was no statistically significant difference $(p=0.417)$ between the two groups in mean age values (Graphic 1). The average height of those in the alcohol consumption group was significantly higher than the average height of the healthy volunteers [176.52 $\pm 7.55(160-190) \mathrm{cm}$ and $170.55 \pm 7.15$ (160-185) cm, respectively, $p=0.016]$. In the alcohol consumption group, the average duration of consumption was 17.25 years, and the average alcohol intake was $256 \mathrm{~g}$ per week.

The average albumin value in the alcohol consumption group was statistically significantly higher than in the healthy volunteer group $[4.50 \pm 0.22(4.00-4.90) \mathrm{g} / \mathrm{dL}$, $4.46 \pm 0.21$ [4.10-4.90) g/dL, respectively, $p=0.04]$. There were no statistically significant differences between the two groups in the other biochemical parameters.

Although the difference between the two groups was not statistically significant ( $p=0.47)$, the mean ADC value obtained by high b value (b 1000) DWI in the alcohol consumption group was lower than in the healthy volunteer group (Graphic 2). The mean ADC value obtained by lower b value (b 400) in the alcohol consumption group was higher than in the healthy volunteer group, but there was no statistically significant difference between the two groups $(p=0.35)$. In both groups, the ADC values obtained with low b value (b 400) and high b value (b 1000) DWI showed statistically significant positive correlations with each other $(r=0.049)$. In both groups, the ADC values obtained with high b value (b 1000) DWI and age showed a statistically significant negative correlation $(r=-0.010)$ (Graphic 3).

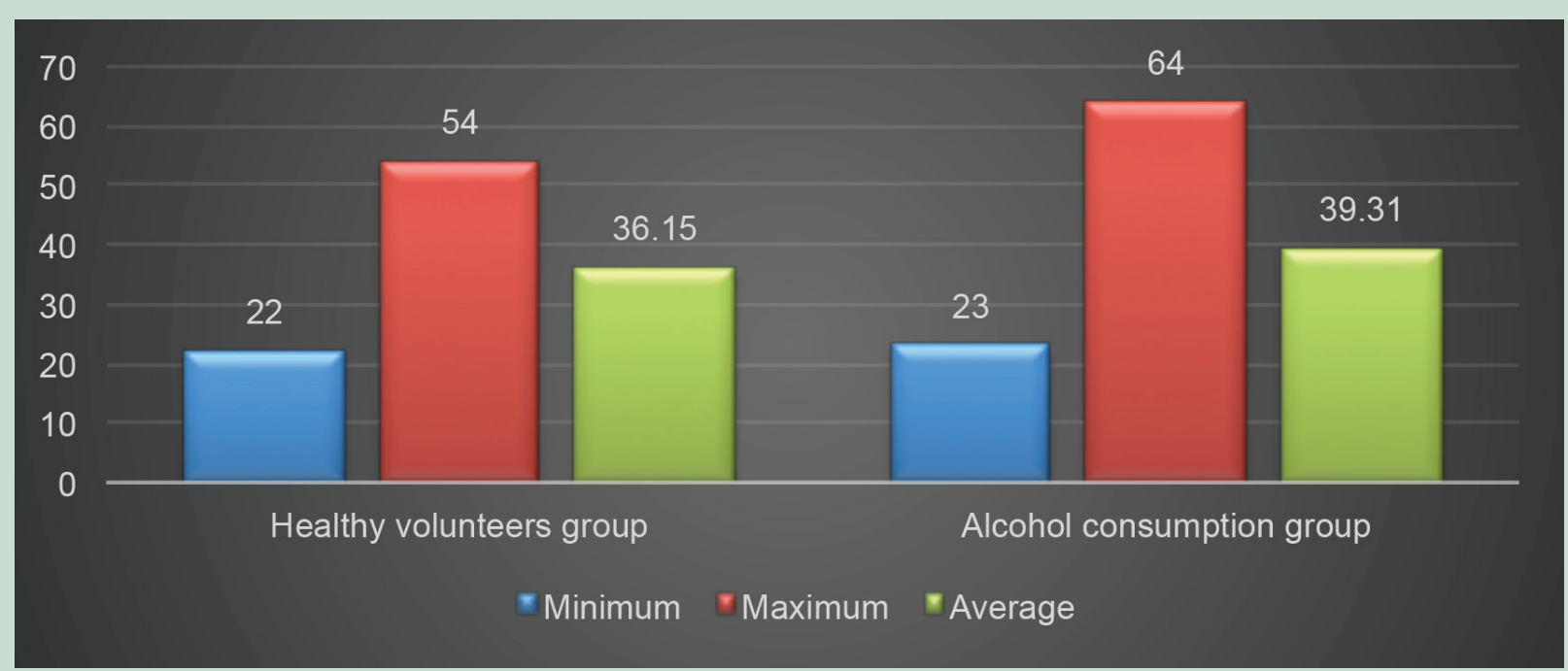

Graphic 1. Age distribution of the study groups. 


$$
\text { * b } 400\left(\times 10^{-3} \mathrm{~mm}^{2} / \mathrm{s}\right) \quad \text { ab } 1000\left(\times 10^{-3} \mathrm{~mm}^{2} / \mathrm{s}\right)
$$

2.5

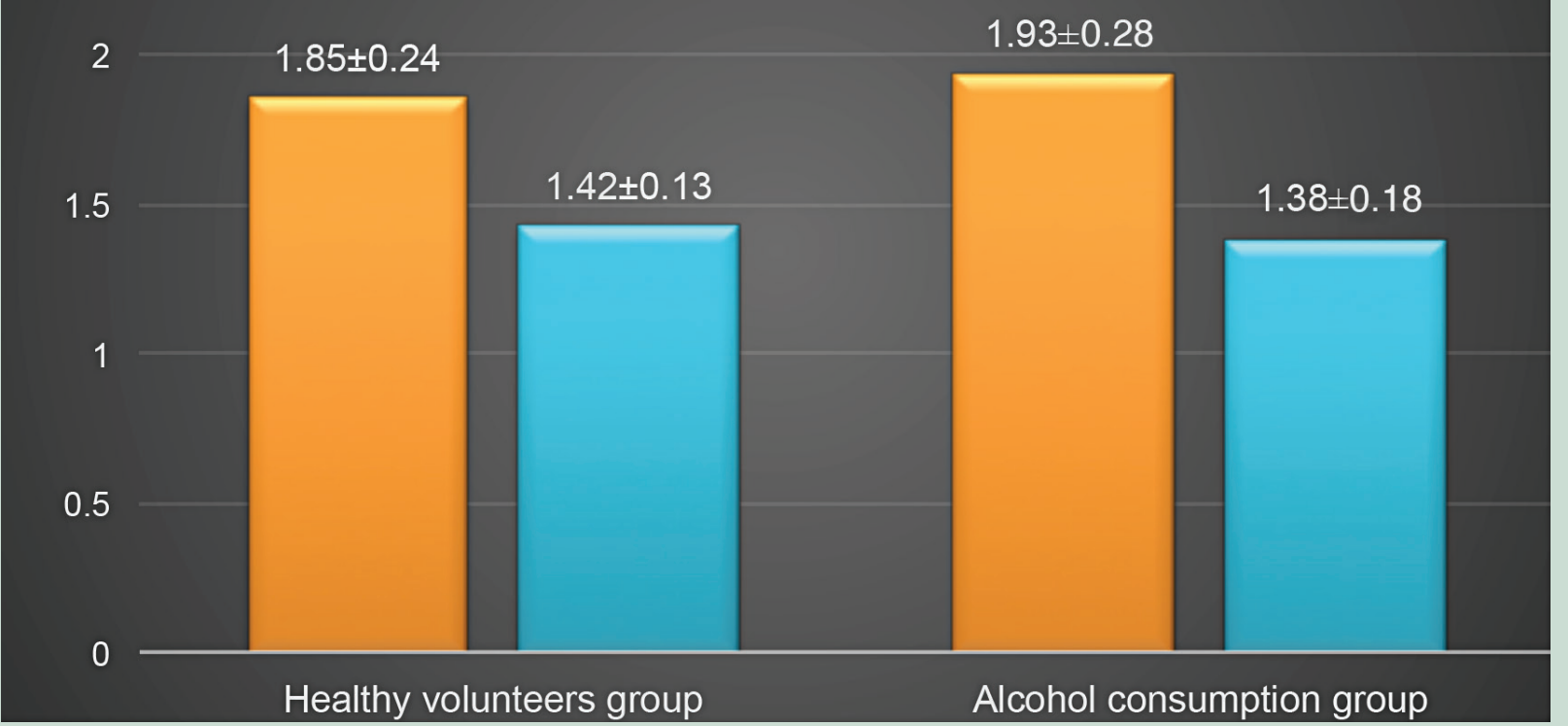

Graphic 2. Mean ADC values of the study groups with low (b 400) and high (b 1000) b values.

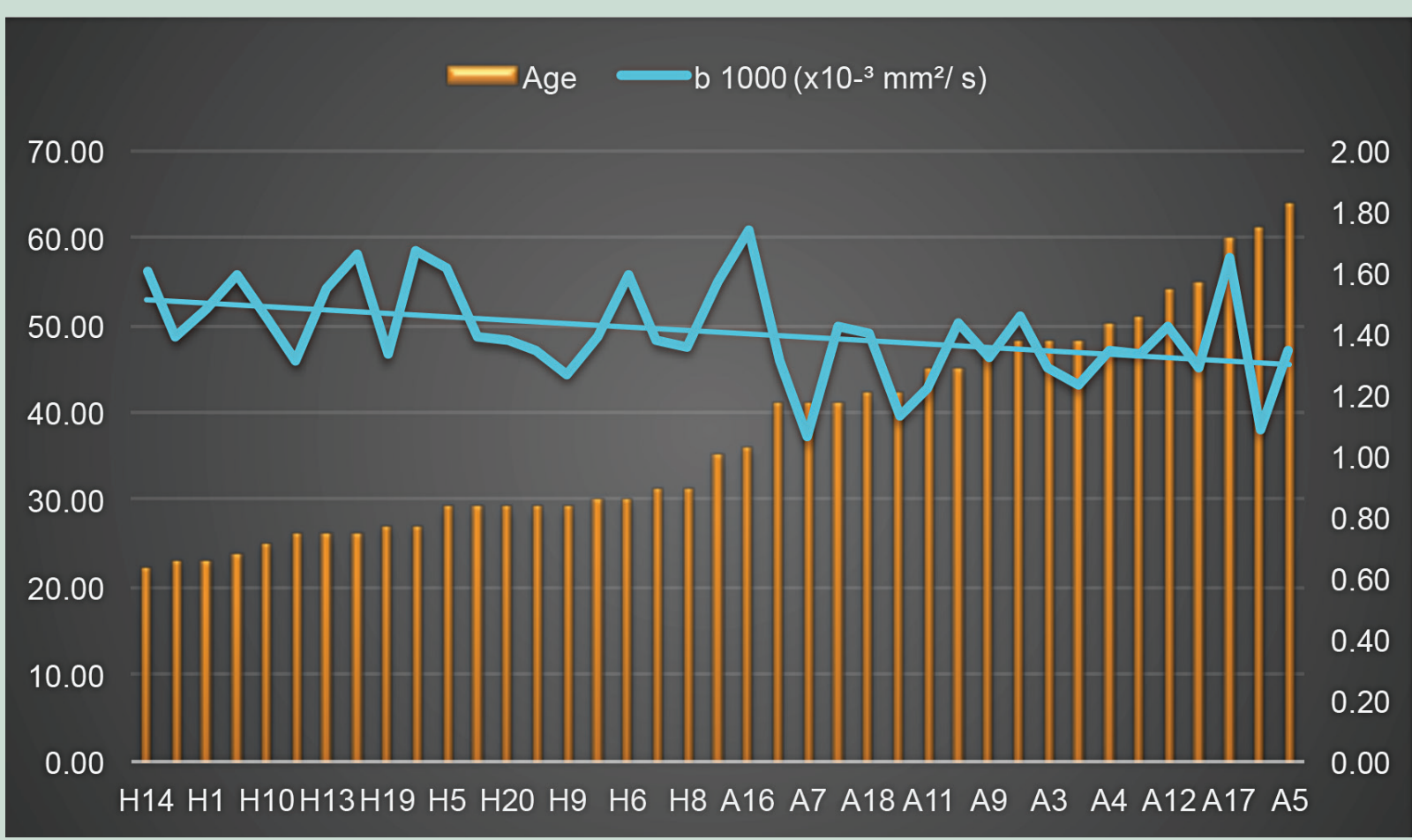

Graphic 3. Age-ADC value relationship of the study groups.

Between the two groups, there were no statistically significant differences in international normalised ratio
(INR), gamma-glutamyl transferase (GGT) and alkaline phosphatase $(A L P)$ values. However, ADC values ob- 
tained with high b value (b 1000) DWI and GGT and ALP values showed statistically significant negative correlations ( $r=-0.007, r=-0.049$, respectively). On the other hand, ADC values obtained with high b value (b 1000) DWI and INR values showed a statistically significant positive correlation ( $r=0.002)$ (Graphic 4-6).

Graphic 4. Relationships between ADC value and GGT of the study groups.

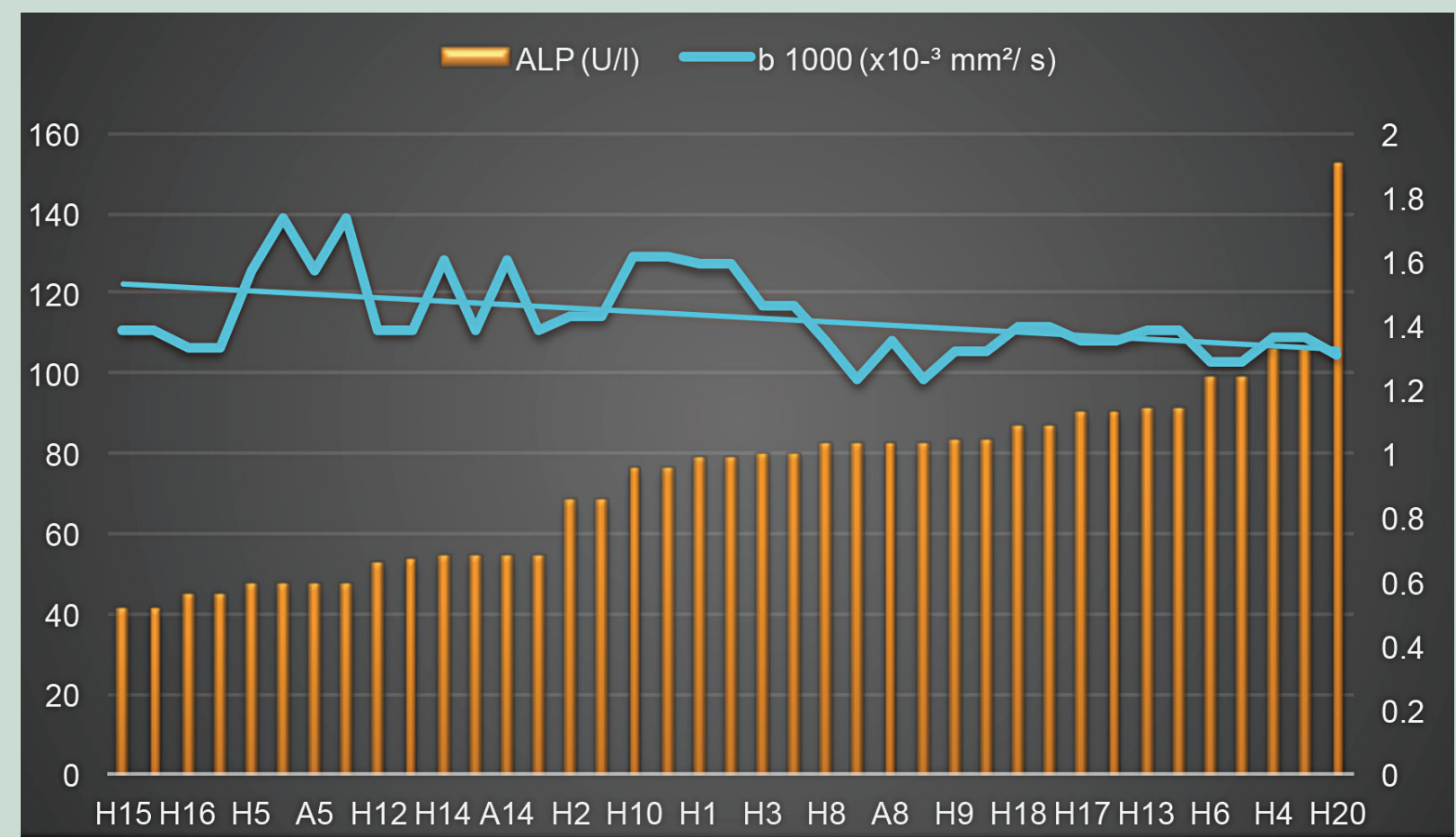

Graphic 5. Relationships between ADC value and ALP of the study groups. 


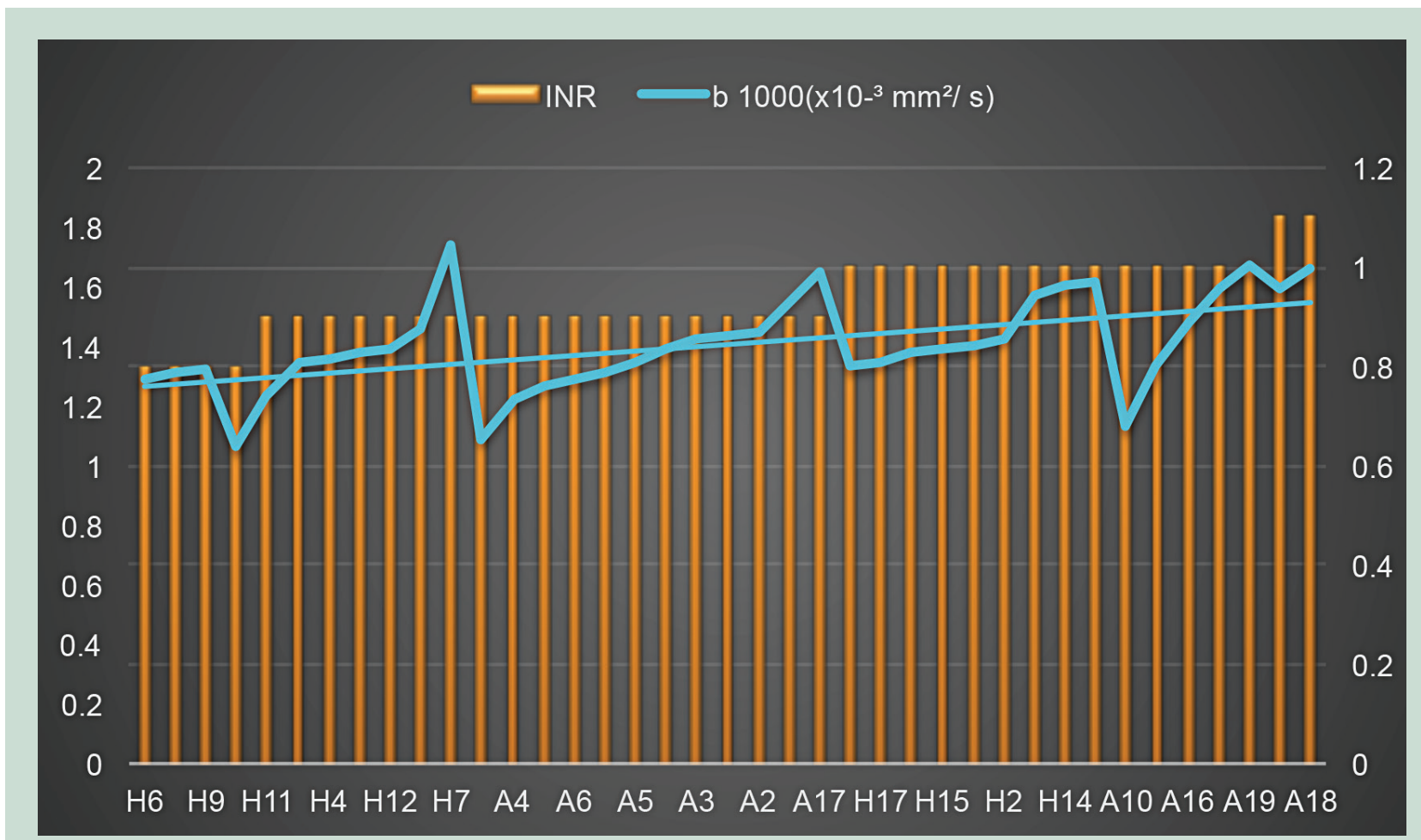

Graphic 6. Relationships between ADC value and INR of the study groups.

\section{DISCUSSION}

Consistent with the literature, this study found that the mean ADC value of the alcohol consumption group was lower than the healthy volunteer group $(8,9)$. Liver DWI can be used for fibrosis screening in alcoholics.

The liver is one of the organ most affected by alcohol consumption. Among individuals who consume more than $60 \mathrm{~g}$ of alcohol per day, 90\% develop fatty liver. This fatty liver may completely reverse after 4-6 weeks of abstinence. However, 5-10\% of patients develop fibrosis and cirrhosis despite abstinence. Persistent alcohol intake (40 $\mathrm{g}$ or more per day) increases the risk of fibrosis and cirrhosis by $30-40 \%$. Perivenular fibrosis occurs in patients who ingest $40 \mathrm{~g}$ of alcohol or more per day for about 25 years. This condition is an independent and significant risk factor for progression to fibrosis and cirrhosis (10).

Alcoholic hepatitis describes a 'disease spectrum' that ranges from mild injury to severe and life-threatening liver damage. Especially for those who drink more than $100 \mathrm{~g}$ of alcohol per day for at least twenty years, this condition occurs in approximately $10 \%$ to $35 \%$ of cases. Even when alcohol consumption is stopped or significantly reduced, alcoholic hepatitis may still occur. Even though alcoholic hepatitis can occur in a mild form, patients with this condition are at high risk of developing progressive liver injury, as cirrhosis develops up to 50\% of the time. With abstinence, histological normalisation occurs in about $27 \%$ of patients. Even with abstinence, alcoholic hepatitis may progress to cirrhosis in 18\% of patients $(11,12)$.

Alcohol-related hepatotoxicity and more severe alcoholic liver disease (with shorter histories and lower alcohol consumption) are seen in women twice as often as in men (13). This may be associated with their higher proportion of body fat, their relatively lower amount of gastric alcohol dehydrogenase, or the effects of menstrual changes on alcohol absorption. However, alcoholic liver disease is more frequent in men because excessive alcohol consumption is twice as common in men.

Micronutrient and protein deficiency, coexisting hepatitis $C$ infection and obesity are listed as prominent risk factors that precipitate alcohol-mediated liver damage. Surprisingly, in this study, the average albumin value in the alcohol consumption group was statistically significantly higher than in the healthy volunteer group.

Excessive alcohol consumption is one of the significant risk factors for liver cirrhosis development and hepatocellular carcinoma (HCC) in industrialised countries. Chronic alcohol consumption induces chronic inflammation, regeneration and hepatocyte necrosis that promote he- 
patic carcinogenesis. Acetaldehyde, which is the main metabolite of alcohol metabolism, has procarcinogenic effects through direct interaction with hepatocyte DNA $(14,15)$. Ikeda et al. reported that total alcohol intake was found to be an independent risk factor and was significantly associated with liver carcinogenesis in all 795 patients in their study (16).

The gold standard technique for the assessment of $\mathrm{fi}$ brotic changes in chronic liver disease is percutaneous liver biopsy. However, it is an invasive method that may lead to such complications as pain, bleeding and peritonitis. Therefore, in recent years, there has been a search for an alternative, simple, reliable and noninvasive method to diagnose and monitor hepatic fibrosis. DWI is a promising technique for this application, and it has been demonstrated in several studies. All 1.5 Tesla MRI devices can easily obtain diffusion images. DWI is known as a cost-effective imaging modality that is fast, noninvasive and does not require contrast media. In addition, DWI is a preferable imaging modality because it can be obtained rapidly $(16,17)$.

DWI was first introduced in neuroradiology for the diagnosis and follow-up of cerebrovascular disease $(18,19)$. Following the development of rapid MRI sequences, such as echo-planar imaging, studies regarding the use of DWI in other parts of the body have been accelerated (20). Today, DWI is a part of the routine liver MRI protocol in many institutions. Several studies in the last decade have investigated the contribution of DWI to the assessment of focal and diffuse hepatic disease $(21,23)$. Important research has assessed DWI capability in the quantification of hepatic fibrosis in chronic liver disease $(22,24,25]$.

In the fibrotic process, the water component of collagen reduces in the liver tissue. As a result, the diffusion capability of water protons reduces in liver tissue in advanced fibrosis. Recent studies confirmed that patients with hepatic fibrosis had lower hepatic ADC values than healthy individuals. The reason for reduced ADC values (limited diffusion) was explained by the fibrotic process with the accumulation of proteoglycans, glycosaminoglycans and collagen fibrils in liver tissue $(17,26)$.

\section{REFERENCES}

1. Federico A, Cotticelli G, Festi D, et al. The effects of alcohol on gastrointestinal tract, liver and pancreas: evidence-based suggestions for clinical management. Eur Rev Med Pharmacol Sci 2015;19:1922-40

2. Koike N, Cho A, Nasu K, et al. Role of diffusion-weighted magnetic resonance imaging in the differential diagnosis of focal hepatic lesions. World J Gastroenterol 2009;15:5805-12.
Previous studies showed that the mean liver ADC values of chronic liver disease and hepatic fibrosis patients were significantly lower than healthy individuals, and there was a negative correlation between fibrosis scores and liver ADC values $(27,28)$. As determined by previous studies, there was a lower mean liver ADC value in the alcohol consumption group than in the healthy volunteer group with high b values (b 1000). However, there was no statistically significant difference between the groups. The reason was considered as, approximately twenty five years alcohol consumption previewed for hepatic fibrosis and cirrhosis process, but in the present study mean alcohol consumption duration is lower that determined by previous studies $(10,12)$.

A study by Piana et al. determined the mean threshold ADC value for $74 \mathrm{HCC}$ cases to be $1.21 \pm 0.28 \times 10^{-3} \mathrm{~mm}^{2} / \mathrm{s}$ (29). In hepatic fibrosis, Hsu et al. determined the threshold ADC value to be $1.31 \times 10^{-3} \mathrm{~mm}^{2} / \mathrm{s}$, Tokgöz et al. determined it to be $1.54 \times 10^{-3} \mathrm{~mm}^{2} / \mathrm{s}$ and Lewin et al. determined it to be $1.21 \times 10^{-3} \mathrm{~mm}^{2} / \mathrm{s}(27,28,30)$. In the present study, the mean ADC value of the alcohol consumption group was $1.38 \pm 0.38 \times 10^{-3} \mathrm{~mm}^{2} / \mathrm{s}$, which is very close to the cut off values for hepatic fibrosis determined by previous studies.

This study has some limitations. Firstly, the number of individuals in the study was low. Also, the duration of alcohol consumption was short. Prospective randomised trials with larger series and adequate duration of alcohol consumption may give more conclusive data. Secondly, abdominal and cardiac movement artefacts might reduce the $\mathrm{S} / \mathrm{N}$ ratio.

In conclusion; consistent with previous studies, the mean ADC value was lower in the alcohol consumption group than in the healthy volunteer group. DWI is a noninvasive imaging method that can be used in detecting and following early liver fibrosis in people with excessive alcohol consumption.

Conflict of Interest: The authors declared that there is no conflict of interest regarding the publication of this article.

3. Moteki T, Horikoshi H, Oya N, et al. Evaluation of hepatic lesions and hepatic parenchyma using diffusion-weighted reordered turbo FLASH magnetic resonance images. J Magn Reson Imaging 2002;15:564-72.

4. Ichikawa T, Haradome H, Hachiya J, et al. Diffusion-weighted MR imaging with single-shot echo-planar imaging in the upper abdomen: preliminary clinical experience in 61 patients. Abdom Imaging 1999;24:456-61. 
5. Soylu A, Kılıçkesmez Ö, Poturoğlu Ş, et al. Utility of diffusion-weighted MRI for assessing liver fibrosis in patients with chronic active hepatitis. Diagn Interv Radiol 2010;16:204-8.

6. Sandrasegaran K, Akısık FM, Lin C, et al. Value of diffusion-weighted MRI for assessing liver fibrosis and cirrhosis. AJR Am J Roentgenol 2009;193:1556-60.

7. Koinuma M, Ohashi I, Hanafusa K, Shibuya H. Apparent diffusion coefficient measurements with diffusion-weighted magnetic resonance imaging for evaluation of hepatic fibrosis. J Magn Reson Imaging 2005;22:80-5.

8. Bakan AA, Inci E, Bakan S, et al Utility of diffusion weighted imaging in the evaluation of liver fibrosis. Eur Radiol 2012;22:682-7.

9. Lewin M, Poujol-Robert A, Boelle PY, , et al. Diffusion-weighted magnetic resonance imaging for the assessment of fibrosis in chronic hepatitis C. Hepatology 2007;46:658-65.

10. Scaglioni F, Ciccia S, Marino M, et al. ASH and NASH. Dig Dis Sci 2011;29:202-10.

11. Basra S, Anand BS. Definition, epidemiology and magnitude of alcoholic hepatitis. World J Hepatol 2011;3:108-13.

12. O'Shea RS, Dasarathy S, McCullough AJ; Practice Guideline Committee of the American Association for the Study of Liver Diseases; Practice Parameters Committee of the American College of Gastroenterology. Alcoholic liver disease. Hepatology 2010;51:307-28

13. Sato $N$, Lindros $K O$, Baraona $E$, et al. Sex difference in alcohol-related organ injury. Alcohol Clin Exp Res 2001;25(5 Suppl ISBRA):40S-45S.

14. Seitz HK, Stickel F. Risk factors and mechanisms of hepatocarcinogenesis with special emphasis on alcohol and oxidative stress. Biol Chem 2006;387:349-60

15. Morgan TR, Mandayam S, Jamal MM. Alcohol and hepatocellular carcinoma. Gastroenterology 2004;127:87-96.

16. Ikeda K, Saitoh S, Koida I, et al. A multivariate analysis of risk factor for hepatocellular carcinogenesis: a prospective observation of 795 patients with viral and alcoholic cirrhosis. Hepatology1993;18:47-53.

17. Aube C, Racineux PX, Lebigot J, et al. Diagnosis and quantification of hepatic fibrosis with diffusion weighted MR imaging: preliminary results. J Radiol 2004;85:301-6.

18. Lutsep HL, Albers GW, DeCrespigny A, et al. Clinical utility of diffusion-weighted magnetic resonance imaging in the assessment of ischemic stroke. Ann Neurol 1997:41:574-80.
19. Warach S, Chien D, Li W, et al. Fast magnetic resonance diffusion- weighted imaging of acute human stroke. Neurology 1992:42:1717-23

20. Muller MF, Prasad P, Siewert B, et al. Abdominal diffusion mapping with use of a whole-body echo-planar system. Radiology 1994;190:475-8.

21. Palmucci S, Mauro LA, Messina M, et al. Diffusion-weighted MRI in a liver protocol: its role in focal lesion detection. World J Radiol 2012;4:302-10.

22. Taouli B, Tolia AJ, Losada M, et al. Diffusion-weighted MRI for quantification of liver fibrosis: preliminary experience. AJR Am J Roentgenol 2007;189:799-806.

23. Colagrande S, Carbone SF, Carusi LM, et al. Magnetic resonance diffusion-weighted imaging: extraneurological applications. Radioln Med 2006;111:392-419.

24. Pasquinelli F, Belli G, Mazzoni LN, et al. MR-diffusion imaging in assessing chronic liver diseases: does a clinical role exist? Radiol Med 2012;117:242-53.

25. Taouli B, Chouli M, Martin AJ, et al. Chronic hepatitis: role of diffusion-weighted imaging and diffusion tensor imaging for the diagnosis of liver fibrosis and inflammation. J Magn Reson Imaging 2008;28:89-95

26. Asu K, Kuroki Y, Sekiguchi R, et al. Measurement of the apparent diffusion coefficient in the liver: is it a reliable index for hepatic disease diagnosis? Radiat Med 2006;24:438-44.

27. Hsu FO, Chiou YY, Chen CY, et al. Diffusion-weighted magnetic resonance imaging of the liver in hepatitis B patients with Child-Pugh a cirrhosis. Kaohsiung J Med Sci 2007;23:442-6.

28. Tokgöz Ö, Ünal I, Turgut GG, Yildiz S. The value of liver and spleen ADC measurements in the diagnosis and follow up of hepatic fibrosis in chronic liver disease. Acta Clinica Belgica 2014;69:426-32.

29. Piana G, Trinquart L, Meskine N, et al. New MR imaging criteria with a diffusion-weighted sequence for the diagnosis of hepatocellular carcinoma in chronic liver diseases. J Hepatol 2011;55:126-32.

30. Lewin M, Poujol-Robert A, Boelle PY, et al. Diffusion-weighted magnetic resonance imaging for the assessment of fibrosis in chronic hepatitis C. Hepatology 2007;46:658-65. 